\title{
Umorul involuntar al propagandei comuniste
}

\author{
Drd. PREDA Gabriel \\ Universitatea „Dunărea de Jos”, Galați
}

Résumé: Nous n'allons pas étudier chacun des aspects thématiques un par un, ce n'est pas l'objet de cette étude, mais quelques cas représentatifs qui méritent d'être présentés afin de bien voir l'influence qu'a pu avoir le parti et son idéologie sur l'univers des anecdotes et des blagues, ce choix réaffirmant pour la première fois un ancrage idéologique qui visaient à redéfinir des lignes des politiques culturelles. On assiste ainsi à un infléchissement de la culture de classe, alors nécessairement ouvrière, à une culture plus partagée, plus démocratique,en circulation orale, donc moins idéologiquement ancrée dans le communisme, mêlant récits réalistes et humour dans une vision populaire, afin de rendre absolument évident le camp dans lequel le lecteur doit se ranger.

Mots-clé: communisme, propagande, manipulation, ridicule.

Unul dintre mijloacele de eficientizare a propagandei în Rusia - ulterior și în celelalte țări contaminate de comunism - a fost cenzurarea și interzicerea opoziției cu tot ce ar fi însemnat ea (partide și orice manifestări). Între sublim și ridicol este numai un pas; el a fost făcut de propaganda comunistă de multe ori și amintim un exemplu notoriu: arta în slujba realismului socialist. Studioul național sovietic a fost înființat în 1920, iar principala-i menire a fost, cel puțin șaizeci de ani, propaganda comunistă. Însuși Lenin a spus-o destul de explicit:

Atât timp cât poporul e analfabet, cele mai importante forme artistice pentru noi sunt cinematograful și circul. [1]

Propaganda comunistă a fost ironizată în multe bancuri, atât în Rusia, cât și în alte țări:

Un membru de partid încearcă să explice cum va fi comunismul:

- Veți avea de toate din belşug: mâncare, haine şi tot felul de bunuri. Veți putea călători în străinătate.

- Aha, zice o bătrână, la fel ca pe timpul țarului. [2] 
Bancul aduce motivul filosofico-literar al celei mai buni lumi posibile. Replica bătrânei depășește ideea de nostalgie; intervenția ei subliniază regresul marcat prin socialism.

În anecdota pe care o cităm mai jos, fabulosul este asociat unei antiteze convenționale (iad-rai); ironia provine din pățania lui Stalin, vehement critic al misticului:

Stalin moare și nu este sigur dacă vrea să ajungă în rai sau în iad. Cere să le viziteze pe ambele. În rai, vede oameni care meditează și spun rugăciuni în şoaptă; $\hat{\imath}$ iad, oamenii mănâncă, beau, dansează, se distrează de minune. Stalin alege iadul. Este condus prin mai multe labirinturi într-o sală unde clocotesc cazane uriaşe. Câțiva diavoli îl înşfacă. Stalin începe să protesteze, țipă că în vizită $i$-au fost arătați oameni care se distrau.

- Aia, îi răspunde un diavol, era propaganda. [3]

Anecdota are, probabil, izvoare comune cu basmul lui Creangă, Ivan Turbincă. Regăsim motivul alegerii între iad și rai, în context oarecum amuzant. Umorul negru imaginează moartea lui Stalin și păcălirea lui, ca o răzbunare pentru răul făcut în timpul vieții.

Prolificul aparat rus de propagandă este parodiat și în bancul următor:

- Care-i deosebirea dintre un basm sovietic și unul occidental?

- Un basm occidental începe: "A fost odată ca niciodată...", pe când un basm sovietic începe „Va fi odată ca niciodată...". [4]

Identificăm aici o suprapunere a conceptelor de basm și propagandă.

Mass-media, literatură, muzică, pictură, dans, arhitectură, teatru, film, nimic nu a scăpat de cenzura și de propaganda în același timp naiv-rizibile și agresive. Însăși denumirea ziarelor și a revistelor este relevantă: Cutezătorii, Scînteia pionierului, Scînteia, Flacăra, Munca. Adesea, cei desemnați a exercita propaganda și cenzura erau indivizi cu nivel intelectual redus, aleși dintre „cetățenii cu origine sănătoasă”. De-a lungul timpului, receptorii tentativelor persuasive comuniste au traversat și traversează diferite grade și reacții: surpriză, amuzament, glumă, ironie; uimirea a devenit râs, apoi cuvenită batjocură.

Politologul Vladimir Tismăneanu a propus o sintagmă realistă care descrie propaganda și intenția PCR: „,secta mesianică“ a comuniștilor. [5] Eugen Negrici a rămas în același câmp semantic, denumind propaganda anilor '80 „reevanghelizarea politică a României”. [6] În manieră leninistă, un reper important al propagandei Partidului Muncitoresc Român (transformat ulterior în PCR) a fost crearea impresiei de călăuză infailibilă.

Principalele cauze generatoare de comic involuntar în auto-elogiul 
practicat de comuniști sunt: redundanța și rigiditatea exprimării (ilustrate în sintagma limba de lemn), tonul voit solemn, asocierile banale de concepte, contradicția propagandă-realitate. Patruzeci de ani, România a asistat la falsificarea evidenței, a fapticului, a cotidianului însuși.

Unul dintre cele mai cunoscute și ridicole falsuri ale biografiei din propaganda ceaușistă a fost modificarea unei fotografii, inserându-i pe Nicolae Ceaușescu și Elena Petrescu (prin căsătorie, Ceaușescu) într-o mulțime de manifestanți regaliști, pro-fasciști. Anturajul lui Carol al II-lea organizase pentru 1 mai 1939 un miting de susținere a monarhiei dictatoriale. După aproape cincizeci de ani de la manifestație, Nicolae Ceaușescu a comandat modificarea unei fotografii realizate la miting, iar mass-media românească și manualele de istorie din 1989 colportează imaginea trucată penibil. Este încă un exemplu al interferenței cultului personalității cu manipularea și propaganda.

Minciuna oficială și-a adâncit ridicolul prin tentativa de a induce românilor convingerea că străluciții conducători s-au cunoscut la respectivul miting socialist (pictorul Eugen Palade a realizat un tablou intitulat 1 mai 1939, unde sunt imaginați alături cei doi viitori fruntași ai Republicii Socialiste România). [7]

Aparatul de propagandă i-a confecționat lui Nicolae Ceaușescu o adolescență glorioasă ca luptător comunist, falsificarea insistând pe conceptele ilegalitate și ilegalist. Replica ironică a socialului s-a constituit în mai multe anecdote și amintim doar una:

- Ai auzit că Nicolae Ceaușescu a fost semiilegalist?

- Cum adică semiilegalist?

- El se ascundea, dar nu-l căuta nimeni.

Această anecdotă și altele concepute în manieră asemănătoare sunt menite a diminua aura eroică a președintelui, indusă de propaganda ceaușistă.

Cei din jurul președintelui Ceaușescu au speculat până și banala coincidență dintre anul nașterii acestuia (1918) și Unire. Sintagme precum cel mai iubit fiu al țării, înțeleptul cârmaci, bărbat între bărbați erau menite atât a-1 măguli pe dictator, cât și a compensa figura neînsemnată, dezagreabilă a lui Ceaușescu. Mitul ceaușist a fost inspirat din aura conducătorului neobosit, urmând modelul Lenin-Stalin:

Tovarăşul Nicolae Ceauşescu, care prin energia sa clocotitoare, prin spiritul său clarvăzător şi îndrăzneț, prin activitatea sa neobosită a imprimat un ritm nou transformărilor revoluţionare din societatea românească, aducându-şi totodată o contribuţie de prim ordin la soluţionarea problemelor complexe care confruntă lumea contemporană. [8] 
Portretul laudativ se remarcă prin epitete bombastice apropiate lirismului agitatoric, iar negarea evidenței creează penibilul. Megalomani și lipsiți de discernământ, Nicolae și Elena Ceaușescu s-au complăcut într-un spectacol grotesc al cultului personalității; de câteva ori pe an, mii de oameni erau obligați să participe la spectacole și mitinguri inspirate din practica sovietică și nord-coreeană. Sloganurile au primit replici parodice:

Ceaușescu reales la al XIV-lea congres! devine La al XV-lea congres, patru ani de la deces!.

După câștigarea Cupei Campionilor Europeni la fotbal de către Steaua București:

N-avem carne și salam, / Dar l-avem pe Duckadam!

Dacă în primul slogan revine ideea macabră a dorinței populare ca Nicolae Ceaușescu să moară, în al doilea simțim un amestec de resemnare și autoironie națională.

Mass-media perioadei socialiste s-a remarcat prin totală obediență; ziarele, radioul, televiziunea, manualele școlare au servit ca tribună de propagare a ideologiei și minciunilor PCR. Bancurile, spuse în șoaptă, au început să circule și pe acest subiect:

- Știi care-i deosebirea dintre emisiunile de radio românești și ziarele românești? In ziare poți împacheta salamul. [9]

Motivul ziarului comunist exista și în bancurile rusești:

- Este posibil să ambalezi un elefant în ziar?

- Da, dacă ziarul conține o cuvântare a lui Hrușciov. [10]

Personajul Hrușciov poate fi substituit aici prin numele oricărui lider socialist: de la V. I. Lenin, I. V. Stalin și N. Ceaușescu până la Fidel Castro, pentru a da un exemplu relativ recent. Toți s-au remarcat prin discursuri enorme, cronofage și lipsite de conținut.

sau

- Ce faci, cum o duci?

- Foarte bine o duc!

- Ziarele de azi le-ai citit?

- Păi, de-acolo știu că o duc foarte bine.

Sistemul Dej a impus o pseudoliteratură care s-a manifestat pe două coordonate: cea antioccidentală (împotriva capitalismului și atributelor burgheziei) și cea proletcultistă. Cea mai agresivă perioadă a înfierării Europei vestice și a Statelor Unite a fost 1948-1964; regimul comunist a folosit mult în propagandă arta (literatura, muzica, desenul, dansul, teatrul, arhitectura și filmul). 
În Epoca de Aur, anii '70 și '80 s-au remarcat prin mii de spectacole unde se prezentau dansuri tematice: costumați în salopete, cu baticuri, căști, băști, dansatorii se angajau în activități muncitorești, pasându-și cărămizi din carton sau construind schele cu maxim entuziasm și grație.

Proza, poezia, teatrul, caricatura, portretizau duş̧manul de clasă ca leneș, lacom, brutal, zgârcit, desfrânat. Omul nou socialist, dimpotrivă: el este harnic, generos, virtuos pe toate planurile, trăiește numai pentru Partidul Comunist. Eficiența mesajului s-a dorit atinsă prin cooptarea unor personalități populare (simpatizate în social) din lumea artistică, sperându-se astfel că omagierea „împlinirilor" și a conducerii comuniste a RSR era mai tolerabilă.

Exemplificăm umorul involuntar al propagandei socialist-comuniste cu niște secvențe de realism socialist, ordonate cronologic:

[...] Dar alt gând acu te doare,/ dintre toate ăl mai tare:/ Acolo la tine-acasă, şade o carte pe masăl Între azimă și blid,/ Dăruită de Partid./ Cartea unde-ai slovenit/ Cum și când s-a făurit/ Țara Muncii ce-a-nflorit acolo la Răsărit.../ Cartea ceea cea mai dragăal Fraților din lumeantreagă-i/ Cartea unde-ai învăţat/ Cum să lupți înverşunat/ Împotriva răilor pentru-ai tăi, pentru popor. /Cartea unde orice rând luminează sângerând şi-n orice slovă din toatel Inimă de om viu bate:/ Armă, flamură şi zid/ Cartea Marelui Partid [...] (Dan Deșliu, Lazăr de la Rusca, 1950) [11]

Macarale/ Râd în soare argintii,/ Macarale, în zori de zi./ Suie-agale,/ Pe albastrelel Cărări/ Macarale/ Suie în zări./ O macara, încetinel/ Mi-a adus un bilețel/ Îl prind iute şi-l citesd "Spor la lucru şi te iubesc!" (Macarale, 1961) [12]

Dunăre, de acum, porți spre Mare nou drum, I Porţi spre Mare mândria, că ce fac şi ce spun, / E şi drept, e şi bun, când te-nalţi, România./ Implinind câte-un vis către veacuri deschis/ Vis de aur romantic, nu la stele visând/ Ci aici pe Pământ am creat dintr-un gând.

(Magistrala albastră, 1984) [13]

Demagogia rizibil-sinistră a propagandei comuniste a fost sintetizată într-o frază remarcabilă a lui Karl R. Popper:

Those who promise us paradise on Earth never produced anything but a hell. (Cei care ne-au promis raiul pe Pământ au produs numai iad.) [14]

Metaforic, enunțul afirmă în mod expresiv contopirea propagandei cu utopia și minciuna. 


\section{Note:}

[1]https://www.digi24.ro/magazin/timp-liber/film/intre-propaganda-sicapodopere-istoria-mosfilm-vazuta-prin-ochii-directorului-868545

[2] Ben Lewis, Istoria comunismului prin bancurile epocii. București, editura Polirom 2015, p. 39

[3] Ibidem, p. 79

[4] Ibidem, p. 332

[5] Vladimir Tismăneanu, Stalinism pentru eternitate. Editura Polirom, Iași, 2005, p. 61

[6] Eugen Negrici, Literatura română sub comunism. Editura Fundaţiei Pro, Bucureşti, 2006, p. 72

[7]https://a1.ro/premium/ceausescu-a-pacalit-23000000-de-romani-a-intrat-incartile-de-is

[8] http://m.adevarul.ro/cultura/istorie/cele-mai-mari-minciuni-manualeleistorie-comunist

[9] Ben Lewis, op. cit., p. 16

[10] Ibidem, p. 226

[11] Cristian Sandache, Literatură și propaganda in România lui Gheorghiu-Dej. București, Editura Mica Valahie, 2006, p. 96

[12]https://www.cotidianul.ro/ce-cantece-se-transmiteau-la-radio-si-tvr-de-1-

mai-in-comunism/

[13] http:/timp-liber.acasa.ro/muzica-293/slagare-romanesti-din-epoca-de-aur-i35038.html

[14] https://en.wikiquote.org/wiki/Karl_Popper

\section{Bibliografie}

\section{Corpus:}

1. Ben Lewis, Istoria comunismului prin bancurile epocii. București, editura Polirom, 2015

2. Cristian Sandache, Literatura și propaganda ìn Romania lui Gheorghiu-Dej. București, Editura Mica Valahie, 2006 


\section{Bibliografie critică:}

1. Vladimir Tismăneanu, $O$ istorie politică a comunismului românesc. Editura Polirom, Iași, 2005

2. Harald Hoffding, Humorul ca sentiment vital. Institutul European, Iași, 2007

3. Claudiu T. Arieșan, Hermeneutica umorului simpatetic. Editura Amarcord, Timişoara, 1999

4. Cezar Tabarcea, Poetica proverbului. Editura Minerva, București, 1982

5. Vladimir Tismăneanu, Stalinism pentru eternitate. Editura Polirom, Iași, 2005

6. Stelian Tănase, Anatomia mistificării. Editura Humanitas, București, 1997

7. Jean-Jacques Wunenburger, Imaginariile politicului. Bucureşti, editura Paideia, 2005.

8. Sorin Alexandrescu, Identitate în ruptură. Mentalităţi românești postbelice. București, editura Univers, 2000.

9. Cătălin Mihuleac, Pamfletul și tableta. Jurnalism sau literatură? Editura „Universitatea Al. I. Cuza”. Iași, 2009

10. Florin Soare (coord.), Politică şi societate în epoca Ceauşescu. București, editura Polirom, 2013

11. Mihai Dinu, Comunicarea. București, editura Orizonturi, 1994

12. Dana Maria Niculescu Grasso, Bancurile politice în ţările socialismului real. București, editura Fundației Culturale Române, 1999

13. Rodica Zafiu, Limbaj și politică. Editura Universităţii din Bucureşti, 2007

14. Cristian Preda, Rumânii fericiți: vot și putere de la 1831 până în prezent. Editura Polirom, Iași, 2016

15. Ilie Rad, Incursiuni în istoria presei românești.Editura Accent, Cluj-Napoca, 2008

16. Eugen Negrici, Literatura română sub comunism. Editura Fundației Pro, Bucureşti, 2006

\section{Webografie:}

1.https://a1.ro/premium/ceausescu-a-pacalit-23000000-de-romani-a-intrat-incartile-de-is

2. http://www.romlit.ro/index.pl/cenzura_vesel

3.http://dilemaveche.ro/sectiune/pe-ce-lume-traim/articol/comunismul-careligie-esuata

4.http://m.adevarul.ro/cultura/istorie/cele-mai-mari-minciuni-manualele-istoriecomunist 
5. http://timp-liber.acasa.ro/muzica-293/slagare-romanesti-din-epoca-de-aur-i35038.html

6. https://www.cotidianul.ro/ce-cantece-se-transmiteau-la-radio-si-tvr-de-1-maiin-comunism/

7. https://www.europafm.ro/helmuth-duckadam/

8.

http://www.monitorulexpres.ro/?mod=monitorulexpres\&p=index\&s_id=56776

9.https://www.digi24.ro/magazin/timp-liber/film/intre-propaganda-si-

capodopere-istoria-mosfilm-vazuta-prin-ochii-directorului-868545

10. https://en.wikiquote.org/wiki/Karl_Popper 